\title{
The Role of Executors in Mariage Properties Sharing Based on Islamic Law
}

\author{
Syuaib Syuaib ${ }^{*}$, M. Taufan B ${ }^{2}$, Ermawati Ermawati ${ }^{3}$
}

${ }^{1}$ Islamic Family Law Department, Postgraduate, Institut Agama Islam Negeri Palu

2 Islamic Family Law Department, Postgraduate, Institut Agama Islam Negeri Palu

${ }^{3}$ Islamic Family Law Department, Postgraduate, Institut Agama Islam Negeri Palu

\begin{abstract}
This study discusses the duties and functions of court bailiff in the settlement of marriage properties or gono gini in the religion court. This study used qualitative method which the data were collected through direct observation and interviews with the religious court staff and judges. The findings show that the tasks and roles of the bailiff at the religious court in solving the marriage properties. They play an important role in carrying out the execution of the marriage properties ot gono gini ssets. In the process of confiscation of the marriage properties, the confiscator is an important component in the final stage of the settlement of a case. The steps or stages of the process of carrying out the confiscation of the bailiffs are waiting for the verdict issued by the head of the judges in the settlement of marriage properties. Importance prospects of thought to the question of duty and fun $g$ of the bailiff to the people as possible with their special studies were made of the court to the public.
\end{abstract}

ARTICLE

INFORMATION 


\section{Introduction}

The Religious Court as one of the judicial bodies in Indonesia based on article 49 of Law Number 3 of 2006 concerning Amendments to Law Number 7 of 1989 concerning the Religious Courts, have the duty and authority to examine, decide, and resolve cases at the first level between people Muslims in the fields of: (a) marriage, ${ }^{1}$ (b) divorce, $^{2}$ (c) inheritance, (d) wills, (e) grants, (f) waqf, (g) zakat, (h) infaq, (i) charity, and (j) sharia economics.

In Religious courts, dealing with the issue of property ownership status during marriage is important to obtain clarity on the position of property, as well as in the case of a divorce, there must be clarity on which are the rights of the wife and the rights of the husband. The husband is not allowed to take the wife's rights and vice versa, the wife doses not take the husband's rights.

In Islamic teachings, if there is a dispute regarding property disputes, it is recommended that it be resolved amicably. However, if it cannot be resolved properly, in Law No. 1 of 1974 Article 37 it is stated that if a divorce

1 See Haerunnisa Yunus, Rusli Rusli, and Abidin Abidin, "The Concept of A Marriage Agreement in the Compilation of Islamic Law," International Journal of Contemporary Islamic Law and Society 2, no. 2 (2020): 33-45; See Syahabuddin Syahabuddin Abd. Rasyid Sidiq, Rusli Rusli, "Gender Analysis of Marriage Guardians in the Compilation of Islamic Law," International Journal of Contemporary Islamic Law and Society 3, no. 1 (2021): 1-14.

2 See Rusli Rusli, "Hermeneutical Reading of Țalāq," HUNAFA: Jurnal Studia Islamika 12, no. 2 (2016): 209-229. occurs in a marriage, joint assets are regulated according to their respective laws. Then the dispute can be requested for settlement to the Religious Court. The Religious Court is a judicial institution which is the executor of justice for all Muslims. ${ }^{3}$

The Qur'an recognizes conflicts and disputes among humans as an inseparable part of life. ${ }^{4}$ Human involvement with conflict has been informed by the Qur'an long before the creation of humans. The Qur'an clearly describes how God's desire to make humans as His vicegerents on earth, was challenged by angels. ${ }^{5}$

The Religious Courts, in examining a case, one of the principles attached to it is the principle of audi alteram partem, namely the principle which basically means that both parties must be heard, both parties who are litigating are entitled to equal and fair treatment ${ }^{6}$ and each must given the opportunity to give

${ }^{3}$ Zainudin Ali, Hukum Islam: Pengantar lmu Hukum di Indonesia,(Jakarta: Sinar Grafika, 2006), h 92

4 See Rusli Rusli, "The Role of Musalahah in Conflict Resolution: A Historical Perspective," Hunafa: Jurnal Studia Islamika 10, no. 2 (December 15, 2013): 203-220.; See Rusli Rusli, "The Role of Family in Preventing Social Conflict in Society From Islamic Perspectives," HUNAFA: Jurnal Studia Islamika 17, no. 1 (2020): 108-122.

${ }^{5}$ Amir Syarifuddin, Hukum Kewarisan Islam (Jakarta: Kencana 2008), 132

${ }^{6}$ Ermawati, E., Musyahidah, S., \& Nurdin, N. (2021). Muslim Society Perspective on Islamic Banking Corporate Social Responsibility in Indonesia (Based On Qur'an and Hadits Economic Themes). International Journal of Business and Management Review, 9(3), 29-40.

e-ISSN: $2715-4580$ p-ISSN: $2715-8268$ 
their opinion. ${ }^{7}$ This means that the judge may not accept information from one of the parties as a basis if the opposing party is not heard or given the opportunity to express his opinion. So that the examination of the case before the trial must take place with the presence of both parties; if one party is not present, the trial must be postponed.

One of the problems that often occur within the scope of religious courts is the distribution of assets. Basically, there is no mixing of wealth in a marriage between husband and wife (harta gono-gini). The concept of gono-gini property originally came from the customs or traditions that developed in Indonesia. This concept is then supported by both Islamic law and positive law that apply in our country. Harta gono-gini applies if the couple does not specify anything else in the marriage agreement. The legal basis for harta gonogini can be traced through the law, Islamic law, customary law and other regulations.

One of the components of the religious court that is active in case management is the bailiff who deals with organizing mechanism in the Religious Courts environment. According to the the article 6 of Law no 2 of 1986 concerning General Courts or Article 103 (1) of Law no. 7 of 1989 concerning the

${ }^{7}$ Muslih, I., Nurdin, N., \& Marzuki, M. (2020). Effectiveness of Marriage Services Through Information System Management (SIMKAH) at Palu City Religious Court INTERNATIONAL JOURNAL OF CONTEMPORARY ISLAMIC LAW AND SOCIETY, 2(1), 20-36.
Religious Courts, bailiff has the task of carrying out summons, which must be carried out responsibly, properly and legally. Each bailiff is appointed and dismissed by the Minister of Justice and Human Rights and Minister of Religious Affairs at the suggestion of the Head of the Court.

Thus, the bailiff is part of the registrar's office of a court as referred to in SK 004/SK/I1/92 of The Supreme Court of the Republic of Indonesia concerning the organization and working procedures of the Registrar's Office of Religious Courts. the Registrar is an auxiliary element of the leadership and is responsible to the chairman, in providing technical services in the field of case administration and other judicial administration based on the law, and serves, among others, to provide trial administration services, as well as the implementation of decisions in civil cases in which the bailiff is involved. 8

The bailiff serves cases involving property matters. One of the lawsuits that entered the court was the problem of the distribution of gono-gini assets, namely the joint property obtained during the marriage. In this case, it is difficult and takes a very long process in resolving the case. This is due to the gap between the two parties that are suing each other. In the implementation of the distribution of the property, the bailiff needs to see legality in a cooperative relationship between husband and wife.

\section{Literature Review}

${ }^{8}$ Mahkamah Agung RI. Praktek Kejurusitaan Pengadilan (Jakarta, 2004), 4.

e-ISSN: 2715-4580 p-ISSN: $2715-8268$ 


\subsection{Definition of bailiff}

One of the functionaries who play a role in handling the mechanism and the judicial organism is an official called a bailiff (formerly known as a deurcwaarder). In the General Courts and the Religious Courts, there are officers called bailiffs and substitute bailiffs. ${ }^{9}$

A bailiff is a civil servant who performs the duties as stipulated in Article 6 (1) of Law no. 2 of 1986 concerning General Courts or Article 103 (1) of Law no. 7 of 1989 concerning the Religious Courts which states that each bailiff is appointed and dismissed by the Minister, namely the Minister of Justice and Human Rights and the Minister of Religion at the suggestion of the Head of the Court. The Substitute Bailiff is the executor of bailiff duties at the General Court and the Religious Court who is appointed and dismissed by the Chief Justice.

The legal basis related to bailiffs can be found in the old regulations, namely Rechterhijke Organization or the Judiciary Structure, in chapter VII. A bailiff is a public official (article 193) who is appointed for performing the tasks as mentioned in article 196 regarding bailiffs. ${ }^{10}$

\subsection{Duties and powers of the bailiff in the Religious court}

9Soebyakto, Tentang Kejurusitaan Dalam Praktik Peradilan Perdata (Jakarta: Kencana. 1997), 1.

${ }^{10}$ Mahkamah Agung RI, Praktek Kejurusitaan Pengadilan (Jakarta. 2004), 4.
The position of the bailiff in the organizational structure of the Religious Courts is to coordinate with the Registrar, whose task is to assist the Registrar, as stated in Article 26 paragraph 2 of Law no. 7 of 1989 concerning Religious Courts. The task of the bailiff in Law no. 7 of 1989 concerning PA is clearly stated in article 103. 11

Before the Law no. 7 of 1989, to enforce the decision by force by the bailiff (deuwarder), including the confiscation of guarantees (conservatoir beslag) to get the goods back (revindicatoir-beslag) still have to ask for assistance from the General Judiciary. However, with the birth of Law no. 7 of 1989, every decision by the Religious Courts no longer needs to ask for assistance or confirmation by the General Court, including in the case of bailiffs. ${ }^{12}$

In Civil Procedure Law, there are two kinds of decisions, final and interim decisions. Final decisions are decisions that end civil cases examined by judges, while interim decisions are those that are held before the judge decides the case, to facilitate case examination. In interlocutory decisions, there are two types of decisions, namely praeparatoir decisions, namely decisions that do not affect the final decision, and interlocutoir

${ }^{11}$ Cik Hasan Bisri, Peradilan Agama di Indonesia (Jakarta: Raja Grafindo Persada, 2000), 126

12Roihan A. Rasyid, Upaya Hukum terhadap Putusan Peradilan Agama (Jakarta: Pedoman Ilmu Jaya,1989), 12

e-ISSN: $2715-4580$ p-ISSN: 2715-8268 
decisions, namely decisions that can affect the final decision. ${ }^{13}$

\subsection{Various kinds of bailiff execution}

The procedural law of the Religious Courts recognizes several types of confiscation in practice, namely:

a. Confiscate Guarantee (Concervatoir
Beslag)
Security confiscation is the confiscation of the defendant's property whose ownership status is disputed or in a dispute over debts or claims for compensation. ${ }^{14}$ In article 227 paragraph (1) HIR and article 261 paragraph (1) R.Bg. it is stated that if there is a reasonable suspicion before the case has been decided in court or it has been decided but has not been carried out, while the defendant tries to embezzle or take away movable or permanent goods, the chairman of the Court at the request of the interested party may order that the confiscation of the goods may be carried out to fulfill the rights of those who submit the application. ${ }^{15}$

From the provisions mentioned above, the characteristics of the security confiscation can be stated as follows:

1. Confiscation of collateral for the property in which the status of the

${ }^{13}$ R. Wirjono Projodikoro, Hukum Acara Perdata di Indonesia, (Bandung, Sumur Bandung,1992), 127

${ }^{14}$ Marzuki Permasalahan dan Penerapan Sita Jaminan Conservatoir Beslag (Jakarta, Pustaka Kartini, 1990),hlm,67

${ }^{15}$ Warkum Sumitro, Perkembangan Hukum Islam di Tengah Kehidupan Sosial Politik di Indonesia, (Malang: Bayumedia Publishing, 2005), h. 182 owner is disputed or the property of the defendant in a dispute over debts or also in a dispute over a claim for compensation.

2. Objects of confiscation, which include movable or immovable goods, can also be carried out on tangible and intangible goods.

3. The imposition of collateral confiscation can be placed only on certain objects, if the confiscation is based on a dispute over ownership (regarding certain objects), or on the defendant's assets until the total amount of the claim is sufficient if the claim is based on debts or claims for compensation. ${ }^{16}$

4. The application must have a reason that the defendant is feared to transfer the disputed goods or collateral, and there are signs or facts that underlie the concern.

In essence, a security confiscation is a confiscation of the disputed property or the defendant's property. This order is issued by the court in a letter of determination at the request of the interested party. The confiscation of the defendant's property can be permanent if the confiscation is followed by an order for delivery to the plaintiff based on a religious court decision that already has a permanent law, or an auction that fulfills the payment of a certain amount of money. ${ }^{17}$

In this regard, in order to avoid misinterpretation or errors in carrying

\footnotetext{
16Ibid,ha 168

17 Abdul Manan, Penerapan Hukum Acara Perdata di Lingkungan Peradilan Agama, (Jakarta,Yasan Al-Hikmah,2000), hal, 60.

e-ISSN: 2715-4580 p-ISSN: $2715-8268$
} 
out this security confiscation, the reference is, the judge must understand that the confiscation of collateral is solely as a guarantee aimed at guaranteeing a lawsuit, and the plaintiff is not empty when the decision is legally enforceable. permanent, and its integrity is guaranteed until the time comes for the decision to be executed. While the rights to the confiscated objects remain with the plaintiff until the decision is carried out by the Religious Court. The confiscated goods remained in the possession of the defendant. This is contained in article 197 paragraph (9) and article 212.

\section{b. Confiscate Revindication}

This type of confiscation is a confiscation carried out by the court on movable objects belonging to one's own which are in the hands of another person, or on one's own property which has been sold but has not been paid for by the buyer. ${ }^{18}$

In article 226 paragraph (1) HIR and article 260 paragraph (1) R.Bg. it is stated that if a person owns movable goods and the goods are in the hands of another person, then that person can request by letter or verbally to the head of the Religious Court in the jurisdiction where he is located and after the decision of the Religious Court has permanent legal force. At the request of the plaintiff, the movable property may be ordered to be handed over to the actual owner. The act of confiscation of movable goods from the hand that owns them is a legal action with the aim of safeguarding the

\footnotetext{
${ }^{18}$ Rasyid Roihan, Hukum Acara Peradilan Agama, (Jakarta, Raja Grafindo,1998), hal, 208.
}

interests of the person who owns the goods so that they are not transferred to another person until the decision on the case submitted is determined by the judge.

\subsection{The concept of gono-gini property}

In Kamus Besar Bahasa Indonesia, the term used is harta bersama (joint property), which legally means, "assets that have been collected during marriage so that it becomes the right of husband and wife"19

In various regions in the country, other terms are also known which refers to the same meaning. For example, in Aceh, joint property is termed haeruta sihareukat; in Minangkabau, it is called suarang; in Sunda, the term is gunakaya; in Bali, druwe gabbro; and in Kalimantan, barang perpantangan. However, the term that is popularly known is harta bersama.

Sayuti Talib said that, "joint assets are those obtained during marriage outside of gifts or inheritance". This is in line with chapter VII concerning property in marriage, Article 35 of Law no. 1 of 1974 which in full reads as follows:

a) Property acquired during marriage becomes joint property.

b) The innate property of each as a gift or inheritance is under the control of each as long as the parties do not determine otherwise.

\footnotetext{
19Pusat pembinaan dan pengembangan bahasa Departemen Pendidikan dan Kebudayaan, kamus besar bahasa Indonesia, edisi kedua, Jakarta: Balai Pustaka, 1995, 342; See also, Ismail Muhammad Syah, Pencaharian Bersama Suami Istri, Bulan bintang, Jakarta, 1965,hal 18
} 


\section{Methodology}

This study uses qualitative approach $^{20}$ investigating the roles of executors in mariage properties sharing based on Islamic law. This study was carried out in religious court of Palu city. Data were collected through field observation, in-depth interviewes ${ }^{21}$ with the court staff and judges. Written materials were also used to analyze the case. Data analysis consists of several procedures which reduction and verification techniques with various data sources. ${ }^{22}$ The reduced data is then analyzed reflecting on theoretical concepts used in this study ${ }^{23}$.

20 Nurdin, N., \& Yusuf, K. (2020). Knowledge management lifecycle in Islamic bank: the case of syariah banks in Indonesia. International Journal of Knowledge Management Studies, 11(1), 59-80. https://doi.org/10.1504/ijkms.2020.105073; See also Rusli Rusli, "Pendekatan Fenomenologi Dalam Studi Agama Konsep, Kritik Dan Aplikasi," Islamica: Jurnal Studi Keislaman 2, no. 2 (2008): 141-153.

21 Rusli, R., \& Nurdin, N. (2021). Understanding Indonesia millennia Ulama online knowledge acquisition and use in daily fatwa making habits. Education and Information Technologies. https://doi.org/10.1007/s10639021-10779-7

22 Muslih, Imam, Nurdin, Nurdin, \& Marzuki, Marzuki. (2020). Effectiveness of Marriage Services Through Information System Management (SIMKAH) at Palu City Religious Court International Journal of Contemporary Islamic Law And Society, 2(1), 20-35.

${ }^{23}$ Iqbal, M., Rusli, R., \& Musyahidah, M. (2019). Management Strategies of Professional Zakat Funds for Mustahiq Family Welfare By Amil Zakat Body International Journal of Contemporary Islamic Law And Society, 1(1), 39-51.

\section{Result and Discussion}

\subsection{Duties and roles of the bailiff in the distribution of gono-gini assets}

The Religious Courts are one of the implementers of judicial power for the people who seek justice who are Muslim regarding certain cases. ${ }^{24}$ In the court, bailiff has duties of examining and adjudicating civil cases. The bailiff and substitute bailiff play an important role in the court, considering their duties and functions in the district court and the religious court. The bailiff is a state official, who is officially appointed with the following procedure; the bailiff is proposed by the District Court and then appointed by the Minister of Justice in accordance with the requirements determined by law.

In the process of resolving cases at the Religious Courts, there are several components that play an important role in deciding cases at the Palu Religious Court, such as judges, clerks and bailiffs. The bailiff of the religious courts plays an important role in carrying out the duties of the judiciary, because if there is no bailiff, the judiciary will not be carried out. The bailiff ushers the verdict and holds special summons for the litigants. ${ }^{25}$ The bailiff acts as a liaison between the judiciary and the litigants. Solman said,

The bailiff is the front line in the case settlement process; in this case the bailiff holds a special summons for

24 Sukarno Aburaera, 2012. Kekuasaan Kehakiman Indonesia. Arus Timur, Makassar, hal. 26

${ }^{25}$ Interview with Muhammad Arsyad, judge, Religious Court, Palu (27 August 2019).

e-ISSN: 2715-4580 p-ISSN: 2715-8268 
people who are litigating and becomes the determination of the law of a case. Then, the trial cannot be carried out if there has not been a summons from the bailiff. ${ }^{26}$

So, before holding a trial of a case in a religious court, the clerk waits for the summons from the bailiff appointed by the substitute clerk to accompany the judge. This is in accordance with the Law on the duties of the bailiff, Law no. 7 of 1989, article 103, and Law no. 2 of 1986 article $65 .{ }^{27}$ Solman said,

In the process of executing gono-gini property confiscation at the Palu Religious Court, the bailiff is an important component in the final stage of case settlement. The process stage in the execution of the confiscation, the bailiff waits for the verdict issued by the chief justice of the court in the settlement of gonogini assets. In carrying out the execution, the bailiff took many steps, the judge appointed the clerk, and then the clerk appointed the bailiff to make two summons. ${ }^{28}$

In Article $196 \mathrm{HIR}$, if the defeated party refuses or fails to fulfill the contents of the decision peacefully, then the winning party submits a request, either verbally or by letter, to the chairman of the district court referred to in the first paragraph of article 195. To implement the decision at that time, the Chairman ordered the summons of the

\footnotetext{
${ }^{26}$ Interview with Solman Abidn, bailiff, Religious Court, Palu (27 August 2019)

27 Mahkamah Agung RI. 2004. Praktek Kejurusitaan Pengadilan. Jakarta, 6

${ }^{28}$ Interview with Solman Abidn, bailiff, Religious Court, Palu (27 August 2019).
}

defeated party, and warned that he must fulfill the decision within the time determined by the chairman, which is a maximum of eight days.

After the stipulated period, if the decision is still not implemented, the Chief Justice of the Court orders the property of the losing party to be confiscated until it is deemed sufficient to replace the amount of money stated in the decision and also add all costs to implement the decision.

The article above can be summarized as follows:

1. Bailiffs and court officials have the right and obligation to notify and deliver other bailiff's letters.

2. Bailiffs and court officials have the right and obligation to carry out orders and decisions of judges. As described above, the order to summon both parties is issued by the chairman of the panel of judges listed in the determination of the first trial day. This is the legal basis for the bailiff to make a summons.

3. If the bailiff and court clerk are absent, then the chairman of the panel of judges must appoint a proper and trustworthy person to carry out the summons and carry out the orders and decisions of the judge.

The final stage of the bailiff's performance is the execution of the property in dispute. Solman said,

In the execution of the confiscation, the execution is carried out by the bailiff after being executed, if the goods cannot be naturally distributed, the goods will be auctioned. After the 
auction, the money will be distributed to the person concerned. ${ }^{29}$

From the interview, it can be concluded that the bailiff has full authority over the distribution of disputed assets. However, the distribution must be in accordance with the verdict. This is in accordance with Article 195 HIR. In civil cases, because the winning party has obtained a judge's decision to punish the opposing party, he has the right according to law to force the opposing party to comply with the judge's decision.

In this case, there is no other way for the winning party except to exercise their rights through the mediation of a judge. However, the decision must have obtained definite force, in the sense that all legal avenues against the decision have been used, or have not been used because the time has passed, unless the decision is declared to be enforceable immediately, despite opposition, appeal or cassation.

\subsection{Islamic Law's Perspective on the Settlement of Gono-gini Property Disputes}

In carrying out his duties, the bailiff at the Palu religious court in resolving the case of the gono-gini property dispute at the Palu Religious Court class 1 A upholds the value of justice for the rights of each individual who is in dispute, according to the vision and mission of the Palu Religious Court, which is in line with the trial of the Prophet.

29 Interview with Solman Abidn, bailiff, Religious Court, Palu (27 August 2019).
A history that tells about the verse about fulfilling the mandate and giving rights to those who are entitled, and punishing justly, is the story of the opening of the city of Mecca. At that time, the guardian of the Ka'bah was 'Uthman bin 'Abd al-Dar, the holder of the key to the Ka'bah. 'Abbas took by force the key. But the Messenger of Allah sent 'Alî to ask 'Abbas to return the key and apologize to 'Uthman bin 'Abd alDar. After that, 'Alî also told 'Uthman bin 'Abd al-Dar that this verse was revealed to him. So 'Uthman bin 'Abd al-Dar embraced Islam. ${ }^{30}$

Although this verse was revealed for certain reasons, it still applies in general terms. The initial command of this verse is to carry out the mandate by giving it to the experts for every Muslim. It includes the rights for himself as well as the rights for others and the rights of Allah in general. ${ }^{31}$

An example of keeping the trust in fulfilling Allah's rights is to obey His orders and stay away from His prohibitions. In carrying out the execution of the case of gono-gini property, the bailiff of the Palu Religious Court class 1A carried out the confiscation execution, by first analyzing the judge's order to execute the case.

Keeping the trust in human rights is like doing something that is beneficial for the world and the hereafter. While maintaining the trust for others is like not

30 'Abd al-Haqq bin Athiyyah. al-Muharrir al-Wajîz Beirut: Dâr Ibn Hazm, 2002, 232

31Ismâ'îl bin 'Umar bin 'Ibn Katsîr. Tafsîr alQur'ân al-'Adzîm. Beirut: Dâr 'Ibn Hazm, 2000, 341

e-ISSN: 2715-4580 p-ISSN: 2715-8268 
cheating when praying, doing jihad, and giving advice.

After establishing the mandate, the next principle is make judgments fairly among people. This is in accordance with the function of the bailiff in carrying out the execution of the above case. The Palu Religious Court, Class 1A, in resolving cases of gonorrhea property disputes, saw the judge's decision, which in the trial, the judge adjudicated according to the rights received from the plaintiffs and defendants. In this case, the court gave a fair decision.

In carrying out their duties, the bailiff at the Palu religious court, in resolving the case of the gonog property dispute, trusted the judge who handled the case. This is because the judges have met the requirements and qualifications to become judges.

\section{Conclusions}

The bailiff at the Palu Religious Court, Class 1A, in carrying out an order to summon or execute a case of a gonogini property dispute, plays an important role. The bailiff has the right and obligation to notify and deliver letters of recommendation for the judge's decision. In this case the bailiff functions as a mediator from the court in carrying out the judge's decision. The bailiff, in carrying out joint property execution activities, is required to look at the condition of the executed person so that they cannot harm themselves or others..

The duties and roles of the bailiff at the Palu Religious Court, Class 1 A, are in accordance with Islamic law. This can be seen from several theories and supporting arguments from all stages of the process from the beginning to the end of bringing a summons to the Palu Religious Court, Class 1 A.

\section{REFERENCES}

Abdul Manan, Penerapan Hukum Acara Perdata di Lingkungan Peradilan Agama, Jakarta, Yasan AlHikmah,2000

Ahmad Rofiq, Hukum Islam di Indonesia Cet.III; Jakarta: Pt Grafindo Persada, 1998

Amin Husein Nasution, Hukum Kewarisan Islam Jakarta:

Rajagrafindo Persada 2012

Amir Syarifuddin, Pemikiran dalam Hukum Islam, Cet. 2 Padang, Penerbit Angkasa Raya: 1993

Arto Mukti, Praktek Perkara Perdata, Yogyakarta,Pustaka Pelajar, 1998

Asghar Ali Engineer, Pembebasan Perempuan, Yogyakarta: Lkis,2003

Basiq Djalil, Peradilan Agama di Indonesia Jakarta: Kencana, 2006

Burhan Bungin, Peneiltan Kualitatif, Komunikasi, Ekonomi, Kebijakan Publik, dan Ilmu Sosial lainnya, Edisi. I; Cet. I; Jakarta: Kencana Prenada Media Group, 2007

Cik Hasan Bisri, Peradilan Agama di Indonesia, Jakarta: Raja Grafindo Persada, 2000

Departemen Pendidikan dan Kebudayaan R.I., Kamus Besar Bahasa Indonesia, Edisi II.Cet. VII; Jakarta: Balai Pustaka, 1996

Departemen Pendidikan Nasional, Kamus Besar Bahasa Indonesia, Cet. II; Jakarta: Balai Pustaka, 2005

Donal Ari, et. al, Introduction to Research, diterjemahkan oleh Arief Rahman, e-ISSN: 2715-4580 p-ISSN: 2715-8268 
Pengantar Penelitian dan Pendidikan, Surabaya: Usaha Nasional, t.th

Ezmir, Metodologi Penelitian Kualitatif Analisis Data, (Cet. II; Jakarta:PT. Raja Grafindo Persada,2011).

Ermawati, E., Musyahidah, S., \& Nurdin, N. (2021). Muslim Society Perspective on Islamic Banking Corporate Social Responsibility in Indonesia (Based On Qur'an and Hadits Economic Themes). International Journal of Business and Management Review, 9(3), 29-40.

H.Sulaiman Rasjid, Fiqih Islam, Bandung : PT. Sinar Baru Algensindo, cet. Ke-33, 2000

Habiburrahman, Hukum Kewarisan Islam di Indonesia Jakarta: Kencana 2011

Husein Umar, Metode Penelitian untuk Skripsi dan Tasir Bisnis, Cet. IV; Jakarta: PT. Raja Grafindo, 2000).

Imron Arifin, Penelitian Kualitatif Dalam Ilmu-ilmu Sosial dan Keagamaan, (Cet. III,; Malang: Kalimasada Press, 1996).

Irawan Suhartono, Metode Penelitian Sosial, Cet. V; Bandung: Remaja Rosdakarya, 2002

JS Badudu dan SM Zain, Kamus Umum Bahasa Indonesia. Cetakan II. Jakarta : Pustaka Sinar Harapan, 1996,

Kompilasi Hukum Islam di Indonesia, Jakarta: Fokus Media, 2007

Kartini Kartono, Pengantar Metode Riset Sosial, Cet. II; Bandung: Mandar Mas, 1990

Kasmir, Dasar-Dasar Perbankan, Jakarta : PT. RajaGrafindo Persada,2014

khoirul muhtarom, eksekusi harta waris di pengadilan agama, JURNAL
RECHTENS, Vol. 3, No. 1, Maret 2014

Lexy J. Moleong, Metodologi Penelitian Kualitatif, (Cet. XVII; Bandung: PT. Remaja Rosdakarya, 2002), 3.

M Idris Ramulyo, Beberapa Masalah tentang Hukum Acara Perdata Peradilan Agama, Ind Hill Co, Jakarta, 1999

M. Yahya Harahap, Kedudukan Kewenangan dan Acara Peradilan Agama, Jakarta, Pustaka Kartini, 1990

Mahkamah Agung RI, Praktek Kejurusitaan Pengadilan. Jakarta. 2004

Marzuki Permasalahan dan Penerapan Sita Jaminan Conservatoir Beslag Jakarta, Pustaka Kartini, 1990

Megi Afrilia, dkk, Efektivitas kinerja jurusita pajak dalam melakukan penagihan pajak pada kantor pelayanan pajak pratama manado dan kantor pelayanan pajak pratama Bitung jurnal Fakultas Ekonomi dan Bisnis Universitas Sam Ratulangi Manado 2014

Metthew B. Milles dan A. Michael Hubarman, Qualitative Data Analisis, diterjemahkan oleh Tjecep Rohendi, Analisis Data Kualitatif. Buku Tentang Metodemetode Baru, Cet. I; Jakrta: UI Press, 2005

Moh.Muhibbin, Abdul Wahid, Hukum Kewarisan Islam Sebagai Pembaruan Hukum Positif di Indonesia Jakara: Sinar Grafika

Mohammed Abu Nimer mediasi dalam hukum Islam Jakarta: PT. RajaGrafindo Persada 
Muhammad Abdulkadir, Hukum Acara Perdata Indonesia. Jakarta, Rineka, 2009

Munawir Sadzali dalam Didin Muttaqien, dkk (ed.), Peradilan Agama dan Kompilasi Hukum Islam dalam Tata Hukum Indonesia Yogyakarta: UII Press, 1993

Muslih, I., Nurdin, N., \& Marzuki, M. (2020). Effectiveness of Marriage Services Through Information System Management (SIMKAH) at Palu City Religious Court INTERNATIONAL JOURNAL OF CONTEMPORARY ISLAMIC LAW AND SOCIETY, 2(1), 20-36.

Ngatno, PTA Medan, Pedoman Praktek Penyitaan pada Pengadilan Agama, 1989

Nur Aisyah, Peranan Hakim Peradilan Agama jurnal Al-Qad Volume 5 Nomor 1 Juni 2018

Nurdin, N., \& Yusuf, K. (2020). Knowledge management lifecycle in Islamic bank: the case of syariah banks in Indonesia. International Journal of Knowledge Management Studies, 11(1), 59-80. https:// doi.org/10.1504/ijkms.20 20.105073

R. Wirjono Projodikoro, Hukum Acara Perdata di Indonesia, (Bandung, Sumur Bandung,1992

R.Soetojo Prawirohamidjojo, Hukum Waris Kodifikasi, Surabaya; Airlangga University Press, 2000

Rasyid Roihan, Hukum Acara Peradilan Agama, Jakarta, Raja Grafindo,1998

Retno Wulan Sutanito dan Iskandar Oiripkartawinata, Hukum Acara Perdata Dalam Teori dan Praktek, Bandung,Mandar Maju, 1997
Retno Wulan, Hukum Acara Perdata dalam Teori dan Praktek, Bandung Bandar Maju, 1997 Arman, Kompilasi Hukum Islam, Surabaya, Pustaka Tinta mas, 1997

Retnowulan Sutantio dan Iskandar Oeripkartawinata, Hukum Acara Perdata dalam Teori dan Praktek, Bandung: Mandar Maju,1995

Robert K.Yin, Case Study Design and Methods, diterjemahkan oleh $\mathrm{M}$. Djauzi Mudzakir dengan judul: Studi Kasus Desain dan Metode, Cet. I; Jakarta: PT.Raja Grafindo Persada, 2002

Roihan A Rasyid, Hukum Acara Peradilan Agama, PT Raja Grafindo, Jakarta, 2000,

Roihan A. Rasyid, Upaya Hukum terhadap Putusan Peradilan Agama, Jakarta: Pedoman Ilmu Jaya,1989

Rosady Ruslan, Metode Penelitian Public Relation dan Komunikasi, Cet. IV; Jakarta: PT. Raja Grafindo Persada, 2004.

Rusli Rusli, "Pendekatan Fenomenologi Dalam Studi Agama Konsep, Kritik Dan Aplikasi," Islamica: Jurnal Studi Keislaman 2, no. 2 (2008): 141-153.

Rusli Rusli, "The Role of Musalahah in Conflict Resolution: A Historical Perspective," Hunafa: Jurnal Studia Islamika 10, no. 2 (December 15, 2013): 203-220.

Rusli Rusli, "Hermeneutical Reading of Țalāq," HUNAFA: Jurnal Studia Islamika 12, no. 2 (2016): 209-229.

Rusli Rusli, "The Role of Family in Preventing Social Conflict in Society From Islamic 
Perspectives," HUNAFA: Jurnal Studia Islamika 17, no. 1 (2020): 108-122.

Rusli, R., \& Nurdin, N. (2021). Understanding Indonesia millennia Ulama online knowledge acquisition and use in daily fatwa making habits. Education and Information Technologies. https:// doi.org/10.1007/s10639021-10779-7

Iqbal, M., Rusli, R., \& Musyahidah, M. (2019). Management Strategies of Professional Zakat Funds for Mustahiq Family Welfare By Amil Zakat Body International Journal of Contemporary Islamic Law And Society, 1(1), 39-51.

S. Nasution, Metode Research (Penelitian Ilmiah), Cet. IV; Jakarta: PT.Bumi Aksara, 2001.

Sarjita, Teknik dan Strategi Penyelesaian Sengketa Pertanahan, Yogyakarta :Tugu jogja Pustaka, 2005

Soebyakto, Tentang Kejurusitaan Dalam Praktik Peradilan Perdata. Jakarta: Kencana. 1997

Sutrisno Hadi, Metodologi Research Jilid I, Cet. XXIX; Yogyakarta : Andi Yogyakarta, 1997

Undang-Undang Nomor 3 Tahun 2006 Tentang Perubahan Atas UndangUndang Nomor 7 Tahun 1989 Tentang Peradilan Agama.

Undang-undang RI nomor 1 tahun 1974 tentang Perkawinan dan Kompilasi Hukum Islam, Citra Umbara, bandung, 2010

Warkum Sumitro, Perkembangan Hukum Islam di Tengah Kehidupan Sosial
Politik di Indonesia, Malang: Bayumedia Publishing, 2005

Winarno Surakhmad, Dasar dan Teknik Research. Pengentar Metodologi Ilmiah, Bandung: Torsito, 1978

Yahya Harahap, Kedudukan Kewenangan Dan Acara Peradilan Agama, Jakarta; Sinar Grafika, 2003

Zainudin Ali, Hukum Islam: Pengantar lmu Hukum di Indonesia, Jakarta: Sinar Grafika, 2006 